\title{
Technology and Urban Freedoms
}

\author{
CEZARY M. BEDNARSKI \\ University of Plymouth \\ United Kingdom
}

\section{INTRODUCTION}

This paper sets out to offer hope that new technologies can bring back lost freedoms and facilitate life after death for architects.

\section{SETTLING OF NOMADS}

Radioactive dating indicates that the microscopic traces of single cell organisms deposited on the oldest fossil rocks are several billion years old - this is the age of life. Cells more complex than bacteria are just over one billion years old. Worms, fish, reptiles and mammals span hundreds of millions of years. The origins of thinking creatures date back some 200,000 years and the first signs of human, settled living come from $10,000 \mathrm{BC}$. Until then people lived a nomadic existence of impermanent ways, constantly moving as they gathered and hunted for food. They harvested but did not sow. The neolithic revolution turned nomads into settled farmers - some 8000 years ago first settlement organisations emerged as a manifestation of new order. Only about 6000 years ago, a number of true cities emerged in the fertile lands of Mesopotamia. Step by step the settled people took power and the nomads went into retreat. Nation states could not tolerate a freely moving people with no geographically based patriotism and who paid no taxes. The dichotomy of a free nomadic life versus the desire for security and stability has been with us for millennia. This conflict has been quite graphically illustrated in the Bible - Cain the tiller of the soil slew his brother Abel, the herdsman. The Lot's punishment after an argument with Abraham and the destruction of sinful cities is equally telling. In the end it was through becoming nomadic, that the Hebrews regained their freedom.

After hundreds of thousands of years of hunting and gathering, of spacial freedom, and after thousands of years of tilling the soil we now live in a new epoch dominated by urban life with our nomadic, freedom-loving instincts being held back. The rise of cities, considered as the second greatest revolution in human culture, was a social process. It was an expression of change in humans interaction with their fellows rather than with their environment. The variety of forms that the early urban societies evolved were the result of different political and economic forces. Their study requires the expertise of social rather than natural sciences. "Cities indicate an anxious quest for permanence transcending the inevitability of human mortality" said H Girardet'.

\section{CITIES}

The emerging of urbanised societies in the 19th century took place not in the region that evolved the first cities over 5000 years ago but in NW Europe. Until the 19th century, the urbanisation of Europe was barely perceivable even despite, for example, the discovery of the "New Worlds". On the eve of the industrial revolution, Europe was largely an agrarian region. Urbanisation is a finite process, a cycle through which societies go in their transition from agrarian to industrial status.

In three billion years, life evolved from single cells able to soak up chemicals, to elaborate systems of cells able to digest ideas. But within the last century alone, technology evolved from the steam locomotive and electric light to the electronic computer, nuclear fusion and space travel. With mind over technology, our rate of development has jumped unimaginably.

Traditionally, cities have been the residence of specialists. Innovation in all areas, including not only technology but also philosophy, religion and science bred in cities. In ORIGIN AND EVOLUTION OF CITIES, Gideon Sjoberg ${ }^{2}$ suggested that the "cause of urban revolution can be correctly interpreted only in relation to the parallel evolution of technology and social organisation (particularly political), these were not just prerequisites of urban life but the basis of its development". Now, although the urbanisation of some countries has already reached $90 \%$, the idea of the city itself has grown cancerous. Jean Nouvel suggests that, "the idea of the city has exploded, the historic notion of the city has no sense today, the modern city does not meet these kinds of definition (...) Urban design is dead." ${ }^{\prime 3}$ The current situation is the result of both social as well as technological advances. The ever larger and denser agglomerations at this new stage in the growth of humanity exceed the grouping size of any large mammal. In fact they resemble more the behaviour of 
communal insects than mammals. At the same time they have brought the deconstruction of togetherness and bodily contacts for the city dwellers.

\section{UNDERLYING STRUCTURES}

Nature moves along the path of least resistance. Energy moves through structures along such paths, and it is the underlying structures that determine the path. The path cannot be changed directly, it can be changed only through the change of fundamental structures. The ability to recognise these structures is crucial in forming new flow paths and creative shaping of our future. The anti-crime measures in Los Angeles, for example, are doomed to failure as they try to alter the resultant least resistance paths of the social depravation while not addressing their structure. High level walkways, fortifications, guns, and closed estates guarded by armed protectors cannot and will not change the structure which brought about the crime. It is these structures that determine behaviour. "Understanding is structure" declared R B Fuller ${ }^{4}$ - thinking isolates events, understanding interconnects them, it establishes relationships between them.

Technology itself is neither good nor bad. It is the structures within which its development flows that have moral charge. $\mathrm{K}$ Eric Drexler in his ENGINES OF CREATION" makes the point quite clearly "genuine courage requires facing reality, facing accelerating change in the world that has no automatic breaks. This poses intellectual, moral and political challenges of great substance (...). Our machines are evolving faster than we - unless we learn to live with them safely, our future will likely be both exciting and short". In our recent history, the technology facilitated Fordism can serve as a serious warning. In addition to being charged with morality, technology is also frequently confused with science. Technology is the solid application of scientific theories - technological and engineering results survive even when scientific theories on which they were based collapse if a new scientific theory can give similar practical results.

\section{DISJOINTED SOCIETY}

"Perceptions are what the future is built upon. The weapons of positive revolution are not bullets and bombs but simple human perception. Bullets and bombs offer physical power but eventually will only work if they change perception and values. Why not go the direct route and work with perceptions and values?" suggests Edward de Bono in his HANDBOOK FOR THE POSITIVE REVOLUTION ${ }^{6}$. We are facing a new society burdened with the potentially paralysing dilemma of individualism versus communitarianism (Hegel, Marx, Wittgenstein, Aristotle). "Neither the external 'freedom from' of the atomic liberal individual nor the communitarian spurious freedom to become some specified something or other that others think 'good' leads to the desired goal of free individuals who, through their freedom achieve both a creative sense of the whole and a creative sense of themselves - a creative sense of belonging" say Danah Zohar and Ian Marshall in QUANTUM SOCIETY?. The exhaustion of traditional, social and political patterns, the opposition of knowledge against experience based on locally rooted cultures has left us with fragmentation of the modern life. We no longer have a consensus on meanings, values, customs or symbols. We thus must re-learn the meaning of the reality as an integrated whole and reach beyond the individual/collective dichotomy. We have no choice but to accept plurality in contrast to the old vision of one truth, one manifestation of reality. The notion of quantum society stems from scientific research, it is a society firmly rooted in nature but not external nature like trees and rivers. This is the nature of physical laws and principles underlying the universe - the structure. "The more (rigidly) connected are the elements of a system, the less influence they will have on the system as a whole ... The more (rigid) the connections, the more each element of the system will exhibit a greater degree of 'alienation' from the whole" says Von Foerster's theorem. In our 'culture of narcissism' (Christopher Lasch ${ }^{8}$ ) we believe mechanistically that in order to create working systems, we need to firmly locate and fix all elements. Things and individuals are perceived to be related through force, and force is an instrument of power. The individual remains alienated from and ignorant of any pattern - he or she is a mere games' player, an actor in some screenplay of which he or she is unaware.

\section{NEW FREEDOMS/NEO-NOMADISM}

What we dream of and strive for is happiness. The definition of happiness varies from Seneka's' 'Non est beatus es se qui non putat (he is not happy who does not consider himself as such) who also held that 'happiness is a serious matter', through St Augustin's DE BEATA VITA" - "happy is the person who has all that he or she wants and who does not want anything evil" to Rashdall's " Happiness represents satisfaction with one's existence as a whole. The Polish writer J Iwaszkiewicz in his ITALIAN NOVELLAS ${ }^{10}$ held that "happiness is too primitive a concept for contemporary man". "A lifetime of happiness. No man alive would bear it, it would be hell on Earth" - this obviously comes from G B Shaw (MAN AND SUPERMAN)" Sir Hugh Walpole in WHAT IS HAPPINESS ${ }^{12}$ published in 1939 said "To confess to happiness today implies a smug complacency and callousness to general misfortunes of the world". Whatever one's view on the issues we would probably agree with the basic ingredients of potential happiness listed by $\mathrm{E} L$ Thorndike in 1943 (MAN AND HIS WORK) ${ }^{13}$.

These are:

- protection against disease causing organisms, poisons and other causes of disaster such as floods, earthquakes, wars, for which the person in question is not responsible. - protection against extreme shock, fear and strain.

- protection by society (via customs, laws and governments) of what is regarded by the existing moral code as a good life. 
- freedom to discover and publish verifiable truths. In the late 60 's, Sir Peter Medawar addressing the British Association as its president affirmed his belief that happiness depends on continuous development in many fields including science and technology. Indeed on the face of it, technology could deal with the majority of the above listed prerequisites of happiness. However, the most worthy of analysis here are the issues of fear and of freedom. Can technology offer us any freedom and can it protect us from fear. That it can take away freedom and induce fear, we know well. A dictionary definition of freedom is "the capacity to exercise choice, in addition to the condition of being free of restraints". "Freedom is a state of mind - not freedom from something but a sense of freedom, a freedom to doubt and question everything (...). To come up in truth, the mind must be completely free without a spot of distraction" said Krishnamurti in FREEDOM FROM THE KNOWN ${ }^{14}$.

Herbert Schiller wrote recently in an introduction to a pamphlet subtitled INFORMATION SUPERHIGHWAY OR CORPORATE MONORAIL?/GLOBAL VILLAGEOR GLOBAL PILLAGE ${ }^{15}$ : "The new technology undoubtedly will dazzle. Yet the purposes to which it will be put will be dismally familiar. Unless strong public sentiment - and there is some - insists on a different course - one with social not market goals foremost, the vaunted electronic information highway will be the road along which a still more pervasive commercialisation of our minds and living space travels." How do we gain and keep our freedom to think, to formulate our own opinions and hold on to them in this age of indoctrination, commercialism and the 'ecology of fear'.

The evangelists of the new computer and communication technology would have us agree that it sets us free and brings us together. According to the architect turned information technology guru, Nicholas Negroponte - "being digital is a liberating state, computers make you mobile and break down artificial barriers between work and leisure, education and entertainment". It is true at present that once equipped with the hardware and linked to the Net (which in itself creates a new global elite) we can communicate with others so connected. It would appear that at present we are free to send down the Net anything we wish without the interference of any state. The message travels through the route of least resistance, and if a given route is blocked, it will take the next best. This implies freedom to define and communicate our beliefs - something that, although frequently only in theory, is the constitutional citizen's right guaranteed by most countries in the world. A recent case of attempted Net censorship under a copyright pretext, the Scientology church against one of its ex-priests, should be watched carefully - it may have far reaching consequences for personal freedom on the Net.

Thanks to technology, our atavistic, nomadic instincts can be nurtured from the comforts of our homes. We can 'surf' the Net world at will, put up 'telepresence' (a term coined by NASA) and 'meet' each other making, in the end, real, physical friendships. Moreover WWW already offers access for remote control of robotics.
The second half of the 20th century has been given a variety of names, I feel that we live in the time of the 'mouse click'. Can we 'click out' anything that we might want? With the looming onset of virtual reality, we will be made able to click our way into travel and other bodily experiences (virtual). We are already clicking our choice of abode teleworking enables us to free ourselves from the need for proximity to our employers. Through increasing devolution of decision making power from centralised bodies, we may be able to click our preference for fresh air and environmental health directly, we can enlighten and lobby each other to this effect. The NET offers a unique feedback power. There are other areas of technology which we can call upon to fulfil our need for freedom from coercion and freedom restriction by those in power. Besides the control of knowledge, the control of energy supply is also the basis of power. But even here technology is able to help. Solar energy is available to all for free. As Norman Foster said in his recent speech, "solar energy gathering design may soon become the vernacular of today". There is no energy crisis. The only crisis is with the access of energy. The Earth is constantly being hit by 10,000 times more solar energy than we use on a global scale. In other words, we are free to use 10,000 times more energy than at present and all of it can be sourced from the solar radiation. This in itself sounds worrying - we tend to use energy either to procure artifacts, or to move about, both of which consume space, and space is the only limited resource we have. Real space that is. Urban life implies compromises resulting from the sheer density of desires. Although the remotely controlled Techno-Home is already with us, with the LonWorks protocol devised by Echelon Corporation becoming an international standard, not all of our desires can be satisfied in such a way as not to interfere with the rights of our neighbours. New information technology and energy gathering processes offer new possibilities in expanding the urban zones of freedom.

\section{THE MOST ELEGANT SOLUTION?}

We are trying to employ technology to deal also with our fear of each other. In some parts of the world Orwell's '1984' predictions are finally being fulfilled. Courtesy of the CCTV we are being watched. This should be perceived as an infringement of our basic right to privacy. In fact, it is being perceived as quite acceptable even desirable. In the UK, City Centre Partnerships in Liverpool introduced CCTV to the city centre to put a check on the growing wave of crime. The police (not directly in control of the system) and the city fathers consider the system a success - obviously. What is more interesting, however, is the public reaction. Out of a small batch of 450 respondents, $70 \%$ replied 'yes' to the question: "Would you feel safer in a shopping centre with CCTV?", and 91\% replied 'no' when asked: 'Do you think CCTV is an invasion of privacy?". Around the world, CCTV is used to displace crime from affluent areas to those where crime is less visible and somehow more acceptable. In his 
pamphlet BEYOND BLADE RUNNER - URBAN CONTROL - THE ECOLOGY OF FEAR, Mike Davis ${ }^{16}$ of THE CITY OF QUARTZ fame, relayed quite a chilling picture of this taking place in LA.

With the advances in the Internet related technology, we will soon be able to watch each other on our computer screens. The next stage in the development of the neighbourhood watch is the voyeur-vision, the new titillation of the Net. Surveillance is a well established cultural phenomenon. Its aim is to ensure that people play roles allocated to them. Tribal group, village and small town life is about surveillance and playing roles. This is what people run away from to the anonymity and privacy of large city life. At a conference on EDGE CITY held at the Royal Academy of Arts in London in 1994, historian Eric Monkkonen appealed to architects 'not to try to give us back communities' reminding that communities stood for patriarchy and control. He felt that architects used the community argument as a means of gaining control of the urban environment. Maybe the reason why people, for the moment, do not seem worried about being watched by CCTV, in addition to the feeling of security (like children playing under the watchful eyes of their parents), is also the fact that there is no personal acquaintance between them and the eyes that watch over them. In a village situation, we know our spies and they know us.

In addition to the communal, there already exists recreational surveillance, like the short wave scanning of the police and cellular phone conversation - a 'reliable' source of journalistic gossip. But we are under other types of surveillance of which we are not fully aware of. This includes data surveillance through banks, credit companies, governments, health authorities and the police. Credit cards are like our footprints for those who want to follow us, spy on our movements, tastes and personalities. In addition to the high definition cameras and directional microphones able to listen to us talking behind the double glazed windows, there is also the LANDSAT satellites linked to the Geographical Information System. Mike Davis predicts that almost certainly by the end of the decade, the largest US metropolitan areas, including LA, will be using LANDSAT systems to manage traffic congestions and oversee physical planning. The same capability of the system can be shared with the police to surveil the movements of electronically tagged individuals and vehicles Orwell in full swing. The Chicago Cabrini-Green housing project uses retina scans to check visitors IDs, and the police are constantly expanding their control over the citizen's freedom of movement. THE ECONOMIST declared recently "as the most elegant solution" a bio-metric surveillance system that can be used without the subject having anything to do at all, without his or her awareness of being scanned. For the moment at least, all these technologies need a critical mass of 'subjects' to be viable. Such mass exists in cities, airports, shopping malls, etc. in other words, urban environments.

\section{SHAPING FREEDOMS}

All of the above has far reaching implications for architects, whose profession faces extinction. It struggles in tragic circumstances - buildings have become commodities with their asset value of more relevance than their function, social and cultural purpose. The ideology of capitalism is rampant as if it were the ultimate word in the evolution of society. The disappearance of architects is near unless they raise their heads, and use their unique skills for the fulfilment of human needs. We need to rebel and become political activists, otherwise we will be confined to the purgatory of the entertainment industry. As the British Architect Cedric Price says: "Architecture should encourage people's appetite to behave in ways which they thought impossible. It should be about well serviced environments and not the vainglorious reputation of architects"'?7. The time horizon for politicians is some two to four years, they have their eyes on personal short-term realisation of ambitions of either reaching for or holding onto power. They always talk about some kind of future, but their role and power are being eroded by new information technology. People will be increasingly able to vote their preferences, directly, without the interface/interference of politicians. The middle seems to be falling out of things, this including both middle management as well as politicians. Architects with their broad education, aimed at forward looking with the skill of chess players (a very aggressive game demanding speed, patience and readiness to make sacrifices in pursuit of long term goals), need to become the visionary agents for society if they are "to avoid being left to pick up the pieces of 'shy" decisions and choices; unless the architectural body takes things in hand, the nature of the decisions will become less and less worthwhile for the society (...). Architects are in a preventative not a curative business", says C Price ${ }^{18}$. Architects are trained to take a holistic view of design and urban growth and many of them have the ability of both imagination and critical visualisation as well as the ease of assimilation of new ideas and technologies. Matisse said that "painters need no dictionaries". Architecture, as an techno/intellectual pursuit, is enmeshed in words, although architects frequently treat words as manure with which they try to ideologically fertilise their work.

Information technology changes the balance of social division thus far based on literacy - anybody with any education can enter the Net and make a change. This is another chance for architects to get up and offer visions which can be related to by the people and accepted as if they were their own. Apparently the majority of visitors to the Building Design magazine stand at the 1995 Ideal Home exhibition in London did not know what architects did potentially a good thing. Architects, preoccupied with form for form's, sake can now sneak out of their unnoticed den and emerge as new forecasters and a creative force able to offer visions on how to circumnavigate future obstacles. Stephen Bayley said in the Times": "The ability to make things efficiently is the modern alchemy (...). The new definite 
trope is 'process precedes product'. The people who own the process own us". Combining the understanding of the process with an empathy for the depth of psychological reactions and feelings is the basis of the architects' training. This may be where our hopes should lie. Architects who decide to explore the technology route must realise that the pace will be ever faster and as a result they will need to adjust to the ever changing meaning of their profession and function. Those, on the other hand, that decide against this route will most probably discover that the world and technology had moved on anyway leaving them behind as entrenched faeces of progress, after all 'the basic direction of (human) organism is forward' as put by H S Sullivan. The decision "matters because the emerging civic structures and spacial arrangements of the digital era will profoundly affect our access to economic opportunities and public services, the character and content of public discourse, the forms of cultural activity, the enaction of power, and the experiences that give shape and texture to our daily routines" says W J Mitchell ${ }^{20}$. Will technology be a thread which will lead us out of the labyrinth and direct towards each other or as D Hollier suggested quoting Georges Bataille, should "we think this Ariadne's thread as itself weaving the labyrinth?"21. But before trying to answer all these questions we should consider the warning offered in 1874 be $\mathrm{E}$ Craster:

the centipede was quite happy until the toad in fun

Said : Pray which leg goes after which? and worked her to such a pitch She lay distracted in the ditch Considering how to run,
In the end 'it is the questions that are interesting, not the answers', said Henri Cartier Bresson.

Copyright CM Bednarski 1995

\section{REFERENCES}

1 H Girardet, The Gaia Atlas of Cities, Gaia Books, 1992

${ }^{2}$ G Sjoberg, Origin and Evolution of Cities, Cities Scientific American, 1965

${ }^{3}$ Jean Nouvel Emmanuel Cattani et Associates, ICA/Artemis, 1992

${ }^{4}$ A C Edmondson, A Fuller Explanation, Birkhauser Boston, Springer Verlag

${ }^{5} \mathrm{~K}$ E Drexler, Engines of Creation, Oxford University Press, 1992

'E de Bono, Handbook for the Positive Revolution, Viking, 1991

7 D Zohar, I Marshall, Quantum Society, Bloomsbury Publishing, 1993

${ }^{8}$ C Lasch, The Culture of Narcissism, Warner Books, 1979

${ }^{9} \mathrm{H}$ Rashdall, The Theory of Good and Evil, 1907

10 W Tatarkiewicz, O Szczesciu, PWN, 1990 (Poland)

11 J lwaszkiewicz, Nowele Wloskie (Poland)

12 G B Shaw, Man and Superman

${ }^{13}$ Sir H Walpole, What is Happiness, 1939

${ }^{14}$ E L Thorndike, Man and His Work, 1943

is Krishnamurti, Freedom from the Known, Victor Gollanch, 1991

${ }^{16}$ Open Magazine Pamphlet Series \#28

17 Open Magazine Pamphlet Series \#23

${ }_{18}$ Cedric Price, RIBA Lecture, London November, 1994

${ }^{19}$ Cedric Price, the Architects Journal Centenary Lecture, 1995

20 Stephen Bayley, Life and Times, The Times, London, 6 October 1992

21 W J Mitchell, City of Bits, MIT Press, 1995

22 D Hollier, Against Architecture, The Writings of Georges Bataille, MIT Press, 1989 